\title{
RESALE PRICE MAINTENANCE AND THE ANTI-TRUST LAWS
}

The state fair trade acts ${ }^{x}$ legalize certain types of resale price maintenance contracts between producers and distributors; the Miller-Tydings Amendment ${ }^{2}$ exempts some of these contracts from the operation of the federal anti-trust laws, if they are valid under state law. The fair trade acts and the MillerTydings Amendment were passed during the depression of the r93o's. They were intended to protect the small retailers from the large retail chains and to increase their bargaining power with large manufacturing units, ${ }^{3}$ but the great depression's destructive effect on retail sales and income was probably the most important single cause. ${ }^{4}$ Economic conditions have changed radically in the United States since these acts were passed. The small retailer has prospered in a period of high incomes and shortages of goods; the government has been faced continuously with the problem of inflation rather than depression. The course of international relations indicates that government expenditure in the foreseeable future will be enormous and, correspondingly, the problem of inflation will remain.

The growing conflict between resale price maintenance and the current economic situation is well illustrated by two recent decisions. The Florida Supreme Court declared the state fair trade act unconstitutionals because economic conditions had changed since the act was passed. The act was no longer a legitimate exercise of the police power for the general welfare. The United States Court of Appeals for the Seventh Circuit held that an agreement between liquor manufacturers on maximum prices to be charged by wholesalers and retailers would not be in restraint of trade. The court said that competition was not enhanced by the ability to charge a higher price but depended instead on the freedom of retailers to cut prices. ${ }^{6}$

Note 28 infra.

2 Note 35 infra.

3 Statement by Senator O'Mahoney (Chairman), Temporary Nat. Econ. Committee, Final Report and Recommendations, at I4I (I94I), "It occurs to the Chair to remark, in connection with this subject, which, of course, is one of very great importance, that many Members of the Senate and the House have believed, with respect to this law, that while it represents apparently a reversal of the general policy of government against combinations in restraint of trade, it was a necessary result of the failure of government in the past to enforce the Sherman antitrust law against the big combinations, and that the demand which has unquestionably arisen from various parts of the country and in many State legislatures for these fair-trade laws has been a result of a desire upon the part of small businessmen to protect themselves from the bad effects of combinations by big business." See the statement by Senator Tydings, Hearing before the Subcommittee of the Committee on the Judiciary on S. 100, 75th Cong. Ist Sess. 40, at $4 \mathrm{I}$ (1937). See the remarks on the Miller-Tydings Amendment by Senator Humphrey, New York Times, p. 36, col. I (Sept. 23, I949).

4 See Grether, Price Control under Fair Trade Legislation 8-Io (I939).

5 Liquor Stores, Inc. v. Continental Distilling Corp., 40 So. $2 \mathrm{~d} 37 \mathrm{r}$ (Fla., 1949).

${ }^{6}$ Kiefer-Stewart Co. v. Joseph E. Seagram \& Sons, 182 F. 2 d 228 (1950), rev'd, I9 U.S.L.W. 407 I (Jan. 2, x95I), on the ground, inter alia, that the fixing of maximum prices also "cripple[s] the freedom of traders." 
The present federal law of resale price maintenance began with the decision in Dr. Miles Medical Co. v. Park \& Sons Co.7 The Dr. Miles Medical Company, a manufacturer of a widely advertised patent medicine, distributed its products through a group of wholesalers and retailers with whom it had price maintenance contracts which set both the price of resale to retailers and the final sale price to consumers. The plaintiff claimed that the defendant fraudulently obtained its product from its wholesalers and then sold it at cut prices. The Court decided that the system of contracts was in restraint of trade and a violation of the Sherman Anti-trust Act.

The next resale price maintenance case decided by the Supreme Court was United States v. Colgate \& $\mathrm{Co}^{8}$ The significance of the case was obscured by procedural complications and an ambiguous indictment and interpretation of the indictment by a federal district court, but the Court decided that in the absence of an express agreement a seller had the right to refuse to sell to those who cut prices. 9

The Colgate decision caused much confusion in the law of resale price maintenance and in the next two resale price maintenance cases, the Court tried to clear up this confusion. The district court in United States v. A. Schrader's Son, Inc. ${ }^{\text {Io }}$ thought that the Dr. Miles decision had been overruled. The Supreme Court said that the court below had misapprehended ${ }^{x x}$ and that the indictment in the Colgate case had not charged either express or implied agreements to maintain prices; the only question in that case had been the manufacturer's right to dispose of his product as he pleased. In Frey \&o Son, Inc. v. Cudahy Packing Co. ${ }^{22}$ the Court again announced that the Colgate case had been misapprehended and that an agreement to maintain prices might be implied "from a course of dealing or other circumstances, the determination of which was a question of fact for a jury." The Court reversed a judgment for triple damages which the plaintiff had recovered under Section 7 of the Sherman Act ${ }^{13}$ on the ground that the facts of the case were insufficient to establish an agree-

7220 U.S. 373 (IgIr).

8250 U.S. 300 (I9I9).

9 Ibid., at 307-8. This was the theory that Justice Holmes had urged upon the Court in his dissent in the Dr. Miles case, 220 U.S. 373, 409 (xgII). Holmes did not limit it to situations where there was no agreement and he always voted to uphold the legality of price maintenance programs. United States v. A. Schrader's Son, Inc., 252 U.S. 85 (I920); Frey \& Son, Inc. v. Cudahy Packing Co., 256 U.S. 208 (I92x); Federal Trade Comm. v. Beech-Nut Packing Co., 257 U.S. 44r, 456 ( 1922 ). Holmes also dissented in Motion Pictures Patents Co. v. Universal Film Mfg. Co., 243 U.S. 502 ( $\mathrm{IgI}_{7}$ ), on the ground that the owner of property (a patent) has the absolute right to keep it entirely for his own use, and therefore he must have the right to part with it on his own terms.

${ }^{{ }_{20}}{ }_{4}$ Fed. 175 , I79-86 (D.C. Ohio, I9I9).

II 252 U.S. 85, 99 (I920).

12256 U.S. 208 (I92I).

1326 Stat. 210 ( 1890 ), I5 U.S.C.A. $\$ \S \mathrm{I}-7$ (I948). 
ment and therefore the trial judge's instructions which had said they were sufficient were in error.

The next resale price maintenance case decided by the Court was Federal Trade Commission v. Beech-Nut Packing Co. ${ }^{x}$ The Federal Trade Commission had issued an order requiring the Beech-Nut Packing Company to cease and desist from carrying out a resale price maintenance program for its products. The Commission claimed that the plan was an unfair method of competition within the meaning of Section 5 of the Federal Trade Commission Act. ${ }^{\text {.s }}$ The Court upheld the Commission's views and distinguished the Beech-Nut case from the Colgate case on the grounds that the Colgate case involved a simple refusal to sell goods and the Beech-Nut Company's methods required the cooperation of its dealers. The Court emphasized the Beech-Nut Company's widespread and efficient use of reporting devices to detect violators. There is also the important difference that the Colgate case was a criminal action brought under the Sherman Act and the Beech-Nut case arose from a cease and desist order under the Federal Trade Commission Act. The Court did mention monopolization in the Beech-Nut case. ${ }^{16}$ This may have been a factor in its decision since one of the points strongly emphasized in the Colgate case in distinguishing it from the Dr. Miles case was that no intent to monopolize had been charged in the indictment. ${ }^{x}$

During this period in the history of resale price maintenance repeated efforts were made to pass federal legislation legalizing resale price maintenance agreements in interstate commerce. The first of these, the Stevens Bill, was introduced in $\mathrm{I} \mathrm{I}_{4}$ and the last of a series of fourteen Kelly bills was introduced in I932. ${ }^{x}$ Early in I933 the 73 d Congress passed the National Industrial Recovery Act and resale price maintenance agreements were included in some retail

$$
\begin{aligned}
& 24257 \text { U.S. } 44 \text { I (I922). } \\
& { }^{{ }^{15}} 38 \text { Stat. } 7 I_{7} \text { (I9I4), I5 U.S.C.A. } \$ 4 \text { I et seq. (I948). } \\
& { }^{x 6} 250 \text { U.S. } 300,354 \text { (IgIg). }
\end{aligned}
$$

${ }^{17}$ Several years later the Court decided that if there was an agency relationship between the manufacturer and distributors, resale price maintenance contracts did not violate the Sherman Act. United States v. General Electric Co., 272 U.S. 476 (r926). In the Dr. Miles case the plaintiff had also contended that the contracts with wholesalers and retailers were agency contracts, but this contention was rejected by the Court on two grounds: that the contracts were really contracts of sale, put in an agency form for legal convenience; and, even if they were bona fide agency arrangements, that the defendant could have obtained the medicines from a wholesaler who had originally purchased the goods not from the Dr. Miles Co. but from another wholesaler and therefore could sell the goods on his own account. The General Electric case can also be distinguished from the Dr. Miles case on the ground that it involved patented articles and the Dr. Miles case did not. For a critical discussion of this case and the general problem of agency in resale price maintenance see Klaus, Sale, Agency and Price Maintenance, 28 Col. L. Rev. 312 (1928).

${ }^{8}$ For an account of these early attempts to obtain federal legislation legalizing resale price maintenance see Seligman and Love, Price Cutting and Price Maintenance 479-84 (1932); FTC, Report on Resale Price Maintenance 39-59 (I945). 
codes. $^{19}$ The claims for these acts were that they would protect the property interest of the manufacturer in the good will of his trade-mark which was being destroyed by retail price cutting and, even more appealing, ${ }^{20}$ they would protect the small retailer from the cutthroat price tactics of the large retail chains. ${ }^{25}$ The chief supporter of these bills was the American Fair Trade League. Although the League had considerable retail support, complete control of its affairs was in the hands of manufacturers' associations. ${ }^{22}$ The extent of retailers' demand for resale price maintenance in this period is difficult to estimate, just as it is difficult to estimate the amount of retail influence on the resale price maintenance systems in the early cases. The late Justice Brandeis (before he joined the Supreme Court) gave intellectual and moral respectability to the League and its measures. ${ }^{23}$ Resale price maintenance, although admittedly a restraint on the free market, began to find a place in American anti-monopoly tradition as the protector of the small retailer from the monopolistic chains.

In the early I930's a separate movement to pass legislation legalizing resale price maintenance gained force in the state legislatures. ${ }^{24}$ There is no indication that manufacturers took any interest in this movement and these acts were exclusively the result of retail pressure. The most active and influential supporter of these measures was the National Association of Retail Druggists. ${ }^{25}$ The proclaimed purpose of the new legislation was much the same as the claims which had been made for the earlier attempts at federal legislation: to protect the good will of the producer's trade-mark, and to protect the small retailer from the cutthroat price tactics of the retail chains.

The first of these fair trade acts was passed in California in $193^{2^{26}}$ and an amended version was passed in I933. ${ }^{27}$ By I936 thirteen other states had passed fair trade acts based on the amended California act. ${ }^{28}$ These fair trade acts had

19 A tabular summary of the NRA provisions relating to minimum prices is given in Lyon, et al., The National Recovery Administration 580-83 (1935). See also Terborgh, Price Control Devices in N.R.A. Codes (I934). The Supreme Court returned federal resale price maintenance law to its original status in I935 when it put an end to the NRA in Schecter Poultry Corp. v. United States, 295 U.S. 495 (r935).

${ }^{20} \mathrm{~A}$ contemporary and sympathetic development of this argument is given by Rogers, Predatory Price Cutting as Unfair Trade, 27 Harv. L. Rev. 139 (1913).

${ }^{21}$ This argument is forcefully made by Brandeis, Cutthroat Prices-The Competition That Kills, 58 Harpers Weekly No. 2969, at IO, I2 (Nov. I5, I9I3): "Shall we, under the guise of protecting competition, further foster monopoly by creating immunity for the price-cutters?" 2 See FTC, op. cit. supra note 18 , at $43-48$.

23 For an account of Brandeis' activity in behalf of resale price maintenance legislation see Mason, Brandeis, A Free Man's Life 424-28 (1947).

24 See FTC, op. cit. supra note I8, at 50-59.

${ }^{25} \mathrm{Ibid}$., at 52-59.

${ }^{26}$ Cal. Stats. (r93r) c. 278.

${ }^{27}$ Cal. Stats. (I933) c. 260.

${ }^{28}$ The provisions of the Illinois Act are typical, except for minor variations which are tabulated and compared in 2 C.C.H. Trade Reg. Serv. II 7OI I-I3 (I949).

"Sec. $x$. No contract relating to the sale or resale of a commodity which bears, or the label 
one unusual feature which raised widespread doubts about their constitutionality: the so-called nonsigner clause. This clause provided that once a manufacturer had signed a fair trade contract with any retailer, it was a violation for any other retailer with notice that a contract had been signed to sell the product at less than the contract price. ${ }^{29}$ After the United States Supreme Court decided that the Illinois ${ }^{30}$ and Califormia ${ }^{31}$ acts did not violate the Constitution, twenty-eight other states passed fair trade acts in the next year. They were based either on the amended California act or on a new model act drafted by the National Association of Retail Druggists which retained all the essential features of the amended California act. ${ }^{32}$ After the United States Supreme Court decision, the various state courts upheld the constitutionality of the fair trade acts. All states now have fair trade acts except Missouri, Texas and the District of Columbia.

So far the courts have not been reluctant to enforce fair trade agreements against signers and third parties, and have allowed damages and injunctive

or content of which bears, the trade mark, brand or name of the producer or owner of such commodity and which is in fair and open competition with commodities of the same general class produced by others shall be deemed in violation of any law of the State of mlinois by reason of any of the following provisions which may be contained in such contract:

(I) That the buyer will not resell such commodity except at the price stipulated by the vendor.

(2) That the producer or vendee of a commodity require upon the sale of such commodity to another, that such purchaser agree that he will not, in turn, resell except at the price stipulated by such producer or vendee.

[There follows an enumeration of certain exceptional situations where goods "may be resold without reference to such agreements."]

Sec. 2. Willfully and knowingly advertising, offering for sale or selling any commodity at less than the price stipulated in any contract entered into pursuant to the provisions of Section I of this Act, whether the person so advertising, offering for sale or selling is or is not a party to such contract, is unfair competition and is actionable at the suit of any person damaged thereby.

Sec. 3. This Act shall not apply to any contract or agreement between producers or between wholesalers or between retailers as to sale or resale prices."

III. Rev. Stat. (Supp. I950) c. I $21 \frac{1}{2}, \$ \S$ I88-9o. The texts of all the state fair trade acts are compiled in 2 C.C.H. Trade Reg. Serv. $f$ 800I-8969 (I948).

${ }^{29}$ See Section 2 of the Ill. Act, note 28 supra.

30 Old Dearborn Distributing Co. v. Seagram-Distiller's Corp., 299 U.S. I83 (I936). The Court relied exclusively on the producers' good will arguments in its decision. This was probably less out of innocence of the facts of retail pressure to fix prices by combination (see Part III and IV infra) than the desire to fit the facts into old and safe categories and thereby to avoid taking up again the already disturbing controversies the Court was involved in over price-fixing concepts. The best known criticism of the Court's view is Shulman, The Fair Trade Acts and the Law of Restrictive Agreements Affecting Chattels, 49 Yale L. J. 607 (r940). An extensive review of the possibilities of extension of the old property and tort categories to resale price maintenance can be found in Chaffee, Equitable Servitudes on Chattels, 4I Harv. L. Rev., 945 (I928).

${ }^{3 x}$ The Pep Boys, Manny, Moe and Jack of Calif., Inc. v. Pyroil Sales Co., Inc., 299 U.S. ז98 (r936).

${ }^{32}$ A classification of the state acts is in FTC, op. cit. supra note 18 , at $67-87$. 
relief on a wide scale. ${ }^{33}$ It has been estimated that in 1948 about five billion dollars' worth of goods bought by consumers were price-fixed by fair trade contracts. This was approximately four per cent of consumers' expenditure on goods which totaled 128 billion dollars. ${ }^{34}$ There is a ceiling on the amount of goods that can be "fair traded" because of the provision found in all the statutes that the goods must be trade-marked. This trade-mark provision is undoubtedly a remnant of the legal theory that it is the manufacturer's property interest in the goods which is being protected by the fair trade laws.

Although the Supreme Court had decided that the fair trade acts did not violate the Constitution, the status of resale price maintenance under the federal anti-trust law had not changed. The Miller-Tydings Amendment to the Sherman Act was introduced to remedy this situation and it was passed in I937.35 The amendment exempts fair trade agreements from the federal anti-trust laws if certain conditions are fulfilled; outside that limited area the federal anti-trust laws are in effect.

The Miller-Tydings Amendment does not mention nonsigner clauses; it only makes legal "contracts or agreements prescribing prices for the resale of a commodity" when they are already "lawful as applied to intrastate transactions." Two cases have been decided on this point so far ${ }^{36}$ and both have held

${ }^{33}$ See the cases collected in 2 C.C.H. Trade Reg. Serv. If 7357-70 (I948).

34 The Not-So-Fair Trade Laws, 39 Fortune Magazine 7o (Jan., 1949). The percentage of goods under price control in the period between 1937 and 1938 has been estimated at somewhere between five and ten per cent. Grether, op. cit. supra note 4 , at 322 . This could indicate that in the following eleven years the amount of goods "fair traded" showed no gain and perhaps a loss. This may be the maximum which the American economy under present competitive conditions is willing to absorb, or it may only be the result of retardation due to the war and long period of price control followed by a very strong seller's market.

35 (The part shown in brackets was added by the amendment). "Section $x$. Every contract, combination in the form of trust or otherwise, or conspiracy, in restraint of trade or commerce among the several States, or with foreign nations, is hereby declared to be illegal: [Provided, That nothing herein contained shall render illegal, contracts or agreements prescribing minimum prices for the resale of a commodity which bears, or the label or container of which bears, the trade mark, brand, or name of the producer or distributor of such commodity and which is in free and open competition with commodities of the same general class produced or distributed by others, when contracts or agreements of that description are lawful as applied to intrastate transactions, under any statute, law, or public policy now or hereafter in effect in any State, Territory, or the District of Columbia in which such resale is to be made, or to which the commodity is to be transported for such resale, and the making of such contracts or agreements shall not be an unfair method of competition under section 5 , as amended and supplemented, of the act entitled 'An act to create a Federal Trade Commission, to define its powers and duties, and for other purposes,' approved September 26, rgr4: Provided further, That the preceding proviso shall not make lawful any contract or agreement, providing for the establishment or maintenance of minimum resale prices on any commodity herein involved, between manufacturers, or between producers, or between wholesalers, or between brokers, or between factors, or between retailers, or between persons, firms, or corporations in competition with each other]." Miller-Tydings Amendment to Section $x$ of the Sherman Anti-trust Act, 26 Stat. 209 (I890), as amended, I5 U.S.C.A. \$ I (r948).

${ }^{36}$ Schwegmann Bros. v. Calvert Distillers Corp., I84 F. 2 d II (C.A. 5th, I950). There is a dissenting opinion by Russell, J., which gives the opposing arguments for a more restrictive interpretation of the amendment. Pepsodent Co. v. Krauss Co., Ltd., $5^{6}$ F. Supp. $9^{22}$ (La., I944). 
that it was the intention of Congress to extend the exemptions of the amendment to nonsigner provisions of the state fair trade acts. Both decisions emphasized the history of the amendment, the awareness of Congress of the provisions of the state fair trade acts, and the general understanding that the MillerTydings Amendment was to be an enabling act for the state fair trade acts.

Similar difficulties are caused by differences in terminology between the Miller-Tydings Amendment and the fair trade acts. This problem came up in a case before a Louisiana federal district court. ${ }^{37}$ The plaintiff, a manufacturer, had entered into resale price maintenance contracts prescribing a minimum resale price for his products according to the wording of the Miller-Tydings Amendment. He brought this action against the defendant on the basis of the nonsigner provision in the Louisiana act. The court decided that since the Louisiana act authorizes only a "price stipulated by the vendor," not a minimum price, the contract was outside the protection of the Louisiana act.

The phrase "in free and open competition with commodities of the same general class produced or distributed by others" has come up in only one case..$^{38}$ The court decided that Kodachrome (color film) was not in the same general class as black and white film and therefore the producer could not take advantage of the exemptions from the anti-trust laws provided by the Miller-Tydings Amendment. The court also decided that the petitioner's product, "magazine Cine-Kodak film," was not sold in free and open competition with other commodities because it was the only product that could be used in a certain type of camera (not produced by petitioner alone).

The scope of the prohibition against horizontal combinations "between manufacturers or between producers" came up for interpretation in United States v. Frankfort Distilleries, ${ }^{39}$ which involved a combination of retailers and wholesalers. The Supreme Court decided that "the Miller-Tydings Amendment does not permit combinations of businessmen to coerce others into making [fair trade contracts]." United States v. Bausch \& Lomb Optical Co.40 decided that the Miller-Tydings Amendment did not protect fair trade agreements from the anti-trust laws if they otherwise violated the anti-trust laws by creating horizontal combinations between wholesalers or retailers. United States v. Univis Lens ${ }^{41}$ decided that the manufacturer of a product which was finished at another stage could not enter into a fair trade agreement with the manufacturer who finished the product and thereby claim immunity from the antitrust laws under the Miller-Tydings Amendment. Some states permit combinations of retailers to enforce fair trade agreements ${ }^{42}$ but there has been no federal

${ }_{37}$ Mennen Co. v. Krauss Co., Ltd., 37 F. Supp. r6r (La., r94r), noted in 3 La. L. Rev. $8 \mathrm{r}_{4}$ (r94r).

${ }^{38}$ Eastman Kodak Co. v. FTC, 158 F. 2d 592 (C.A. 2d, r946).

${ }^{39} 324$ U.S. 293 (r945).

${ }^{40} 3^{2 I}$ U.S. 707 (I944), aff'g 45 F. Supp. 387 (N.Y., I942). $\quad{ }^{41} 3$ I6 U.S. 24 I (I942).

${ }^{2}$ Port Chester Wine \& Liquor Shop v. Miller Bros. Fruiterers, 28r N.Y. ror, 22 N.E. 2d 253 (I939). 
decision on this question. Nor has there been any federal decision on retailers' and manufacturers' associations which undertake advisory functions in the establishment of fair trade agreements.

The fair trade acts and the Miller-Tydings Amendment must be evaluated in the context of their economic operation if their relationship with the antitrust laws is to be understood. An individual manufacturer, whether or not he occupies a strong monopoly position, has nothing to gain from maintaining resale prices at some arbitrary level. There is nothing to stop a manufacturer from charging his distributors as high a price as is compatible with what he considers to be his own best interests, whether this be large immediate profits or maximum average profits over some longer period. The competing distributors will drive down retail prices to a point where they can just cover the cost of handling the product. Lower retail prices will increase the quantity of the product sold without affecting the manufacturer's profit per unit. A system of resale price maintenance would reduce the quantity sold, depending upon how much the maintained price exceeded the competitive price, and how sensitive consumer demand for the product was to price. ${ }^{43}$ The manufacturer would gain nothing he could not have had before by raising his prices to the distributor.

Kiefer-Stereart v. Joseph E. Seagram $\&^{\circ}$ Sons $^{44}$ is an interesting illustration of this analysis. The defendant liquor distillers set maximum wholesale and retail prices for their product. The plaintiff, an Indiana wholesaler, claimed that the defendants had conspired to fix prices to his injury. The defendant's behavior in setting a maximum retail price, while more rational than setting a minimum price, still makes little sense unless he were facing concerted action on the part of the wholesalers. If the wholesalers were competitive, they would drive the price down and there would be no need for the manufacturers to set a maximum price. There is some indication in this case that the wholesalers were acting in concert 45 and on this theory the defendant's behavior is a rational defensive measure to maintain the volume of his sales and maximize his revenue.

There are some market situations which provide exceptions to the general rule. Some products are of such ephemeral value that a steady and relatively high price is their most substantial market characteristic. Such products account for the only market situation where the producers' good will theory explains the manufacturers' preference for resale price maintenance. Hartman's "Peruna" ${ }^{6}$ (reputed to have been remarkably similar in effect to alcohol) and

43 See the discussions of elastic and inelastic demand curves in Boulding, Economic Analysis (I948), and Stigler, The Theory of Price (1946).

${ }_{44}^{4} 82$ F. 2 d 228 (C.A. 7 th, I950), cert. granted 7 I S. Ct. 89 (I950).

45 Ibid., at 230-3I.

${ }^{4}$ Peruna was a medicine involved in a resale price maintenance case which preceded the . Dr. Miles case. Fowle v. Park, I3I U.S. 88 (I889). The Court upheld the resale price maintenance system, but the circumstances were considerably different from those in the Dr. Miles case. 
Dr. Miles' medicines were probably vulnerable to thought, however induced, and even lower retail prices might have tumbled the delicate sales structure. But such products are quantitatively of little importance and the sales of most products will benefit from price reductions. ${ }^{47}$ Even products which have some "luxury" characteristics in the market will usually experience an increase in sales from lower prices which will more than offset the decrease caused by a loss of "snob appeal."

There is a second exception which may have much more general significance. Some manufacturers sell through retail distributors with widely different cost structures represented by substantial differences in sales and other services offered to their customers. These services may be of considerable value to the manufacturer by increasing sales for all distributors and therefore worth paying for. The manufacturer could charge such high-cost distributors lower prices than those charged other distributors to avoid the higher retail prices which would otherwise be necessary. But such a system might be difficult and expensive to administrate, might cause much dealer discontent, and since 1936 would probably be a violation of the Robinson-Patman Act..$^{8}$ An alternative is resale price maintenance. By setting a high enough retail price, the manufacturer can assure the dealers who "advertise" his product a satisfactory profit by eliminating price competition from the "free riding" low-cost retailers. 49 This is particularly satisfactory if the sales promotion of the high cost retailer has a large "spilling over" effect in the markets of the low-cost, minimum-service retailers, and if the quantity sold by the low-cost retailers is not very sensitive with respect to price.

There is a good possibility that in industries with a small number of large manufacturers an attempt will be made by the manufacturers to eliminate price competition among themselves by setting uniform wholesale and retail prices in fair trade contracts. This would undoubtedly be a violation of the provision against horizontal combinations in the fair trade acts and the Miller-Tydings Amendment, but the burden and expense of proof would be on the anti-trust enforcement agencies since such contracts are at least presumptively legal. An arrangement like this would work particularly well in an industry where the demand for the product is relatively inelastic with respect to price changes. There is some evidence that this has already happened in some industries.50

47 The most infuential contemporary study of the theory of demand rejects the idea of a positive sloping demand curve (i.e., products of which less will be sold as the price decreases). "Thus, as we might expect, the simple law of demand-the downward slope of the demand curve-turns out to be almost infallible in its working. Exceptions to it are rare and unimportant." J. R. Hicks, Value and Capital 35 (I946). The exceptions that Hicks considers do not even include the phenomena discussed here.

${ }_{48}^{89}$ Stat. I526, I5 U.S.C.A. \& I3 (Supp., I949).

49 This seems to have been the situation in United States v. Bausch \& Lomb Optical Co., 321 U.S. 707 (I944), with the exception that, in this case, the manufacturer attempted to eliminate cut-rate retailers entirely. This situation may also have been an important element in the Dr. Miles case.

so See FTC, op. cit. supra note 18, at LVI and 537-49. 
The economic interest of retailers is easier to understand than that of the manufacturers. Retailers expect the benefits of monopolistic combination in the form of high retail prices which it is assumed will also yield high profit margins and high total profits. The fair trade acts through the nonsigner clause organize a retail combination as soon as a resale price maintenance contract has been signed by a manufacturer and any one retailer. It is naive to expect that the same group of retailers (or a powerful subgroup) is not aware of this fact before the contract is signed and is not willing to help the process along. This is particularly true since it is known that many of the retail groups affected are already organized and were instrumental in having the fair trade acts passed. Even more disturbing to any other analysis is the fact that most manufacturers have nothing to gain by imposing resale price maintenance "from above."

If the retailers in a particular industry are well enough organized, they can force manufacturers into resale price maintenance agreements whether or not the manufacturers would otherwise find such an arrangement beneficial. The manufacturer will still have the choice of raising the resale price by the full amount of the retailers' increased profit margin ${ }^{52}$ or absorbing some of the retailers' gain directly by lowering his own price to distributors. His decision will depend on his estimation of consumer reaction to a price increase, and the extent to which he thinks the quantity of sales will fall off for any given increase in price. If he thinks there will be a large decrease in sales he is apt to be willing to absorb the loss directly by reducing his own prices to distributors. If he thinks there will not be a great decrease in sales he will probably choose to set high resale prices and let the consumer absorb most of the loss.

There are two essential features for a successful horizontal combination: the ability to assure compliance by the members to prices set (and to whatever other rules are necessary); and the ability to limit membership in the combination so that monopoly profits are not eaten up by increased numbers of dealers, who are attracted by the large profits, entering the industry. The fair trade

sx In actual practice the provision against horizontal combinations in the fair trade acts and the Miller-Tydings Amendment have been ineffective in preventing the type of practices held illegal in United States v. Frankfort Distilleries, note 39 supra. The FTC has claimed that most of the resale price maintenance contracts in existence violate the provision against horizontal combination, but that the federal anti-trust law enforcement agencies do not have the money with which to enforce the law adequately by examining every price maintenance contract involving interstate commerce. FTC, op. cit. supra note I8, at LXI.

52 Retailers' organizations have consistently claimed that they wanted most to protect themselves from destructive price cutting by resale price maintenance but at the same time they have placed greatest emphasis on large profit margins in their trade literature. Even the Unfair Trade Practices Acts which prohibit selling below cost have been turned into devices for guaranteeing a high rate of profit to retailers by defining cost so that it means the cost plus profit of the highest cost sellers in the industry. The National Association of Retail Druggists has always emphasized in its trade literature a $33^{\frac{1}{3}}$ per cent margin over selling price ( $5 \circ$ per cent over cost) for retailers. Resale price maintenance was simply one step to this end. See FTC, op. cit. supra note I8, at 2I2-x8. For a discussion of the unfair trade practices acts see note, Sales below Cost Prohibitions: Private Price Fixing under State Law, 57 Yale L.J. $39 \mathrm{I}$ (r948). 
acts through the nonsigner clause solve one of the problems of enforcement. All the retail sellers of a "fair traded" product must "join" the combination if they are to sell the product at all. How effective this will be in practice depends upon the ability of the retailers' association to make the manufacturer enforce the resale price set, or if the law permits, the association's ability to enforce the price effectively itself. 53 But the other problem of successful trade combination has not been solved by the fair trade acts. New sellers are not prevented from entering the field to enjoy the high retail profits and to drive down total profits per retailer by decreasing everyone's share of the market. A depression in retail sales is likely to arouse much greater interest in this defect (from the retailers' point of view) in the existing law and considerable political pressure to remedy it. There are already signs of difficulty, 54 and the longer English experience with legalized retail price maintenance bears out this prediction. 55

The most popular anti-monopoly argument for resale price maintenance is still a variation on the old Brandeis theme. Loss-leader selling of widely advertised products by the large chains lures customers away from their more legitimate competitors. The chains then recoup their losses by selling other less well known, or nontrade-marked, products at high prices to the customers they have attracted..$^{56}$ The most noticeable thing about this argument is that it rests entirely upon the assumption of consumer irrationality. ${ }^{57}$ There is nothing to stop the housewife who is attracted by the low prices from taking full advantage of these prices and then returning to the retailer whose general price level is lower. She may be beguiled into paying higher prices for the same thing because of elaborate advertising or attractive packaging, but it is extremely doubtful whether she will pay higher general prices for the same articles because a retailer has sold her a limited number of articles at a distinctly lower price. The supplementary assumption that purchasers know only the prices of widely advertised

53 See note 42 supra.

54 In New York the legislature has made resale price maintenance compulsory in the liquor industry and instituted state enforcement procedure because private resale price maintenance contracts and enforcement procedure had not solved the problem of price cutting in the industry. N.Y. Alcoholic Beverage Control Law $\$$ I7 (I2) (I945); Division of Alcoholic Beverage Control, Rule 26 (r947). See Compulsory Resale Price Maintenance in Liquor: a New York Experiment in Controlled Competition, 57 Yale L.J. 458 (1947).

ss For an account of the efforts in England to coordinate restricted entry into retailing with resale price maintenance see Grether, Price Maintenance in Great Britain, 48 Q. J. Econ. 620, 637-4I (I934).

${ }^{56}$ See statement of Senator Tydings, note 3 supra; see also additional statement of Senator Tydings. Ibid., at $42-44$.

57 It is interesting that the mathematical models of loss-leader policy constructed by economists are not based on the assumption of consumer irrationality but adopt assumptions compatible with rational consumer behavior: (I) that the product sold as a loss leader and the product the sales of which are expected to benefit are complementary in consumer demand, e.g., razors (the leader) and blades; (2) that the seller be a monopolist, i.e., the consumer cannot go across the street to get a close substitute (blades) at a lower price. For a discussion of these and other necessary assumptions see Allen, Mathematical Analysis for Economists 359-62 (I948), and Roos, Dynamic Economics I28-47 (1934). 
trade-marked goods is extremely dubious. Consumers know best the prices of the things they purchase most often. Closely related to this anti-monopoly argument is the contention that the consumer benefits from resale price maintenance because loss-leader tactics are eliminated..$^{8}$ This argument also rests upon the assumption of consumer irrationality. Whether the consumer should be protected by law from his own irrational behavior about variations in price is still an open question.

The basic issue of the Miller-Tydings Act is whether it should be the policy of the United States to encourage the growth of retail combinations. It is true that there is an express provision in the Miller-Tydings Amendment and in the fair trade acts against horizontal combinations, but unless the spirit of these provisions was violated, the fair trade movement would make little economic sense. The Department of Justice and the Federal Trade Commission have claimed that the great majority of fair trade agreements in interstate commerce are probably in violation of the provision against horizontal combinations. But the anti-trust enforcement agencies do not have sufficient funds to investigate all the contracts made and to enforce the provision against horizontal combinations. ${ }^{59}$ If they did, the fair trade acts would in effect become something very different, and of much less economic interest and importance.

\section{TRADE ASSOCIATION STATISTICS AND THE ANTI-TRUST LAWS}

Most trade associations in the United States have engaged at one time or another in collecting and distributing industry statistics. The movement is usually said to date from the publication in IgI2 of Mr. A. J. Eddy's book The New Competition, which had as its thesis that "[t]rue competition begins with

${ }^{8}$ One of the early bills introduced to legalize resale price maintenance contracts in interstate commerce (the Stephans Bill introduced in the 64th Congress) was presented as a bill "to protect the public against dishonest advertising and false practices in merchandising." The Fair Trade League was the chief sponsor of the bill and at the annual meeting of the League the following dialogue took place:

Mr. Arend: Is it in the best form to get what we want? Has it a false caption? It has as I look at it.

Mr. Geissler: I don't think it is ambiguous. I thought the sops included were advantagestrading points, so to speak.

And later Mr. Arend said, "I am skeptical about the consumer arguments .... I don't like the sham in it." FTC, op. cit. supra note 18 , at $45-47$.

The most careful analysis of the economic advantages to the consumer of resale price maintenance was made by Prof. F. W. Taussig; he decided that the consumer arguments were not to be taken seriously enough to warrant a conclusion favorable to resale price maintenance. 6 Am. Econ. Rev. Supp. I5 (zgr6).

There have been several statistical studies of the effect of fair trade agreements on prices and the studies, while inconclusive, have all indicated that prices of the same products are higher in fair trade states than in the noy-fair trade states. See FTC, op. cit. supra, at XIV-L.

${ }^{59}$ See note $5 \mathbf{x}$ supra. 